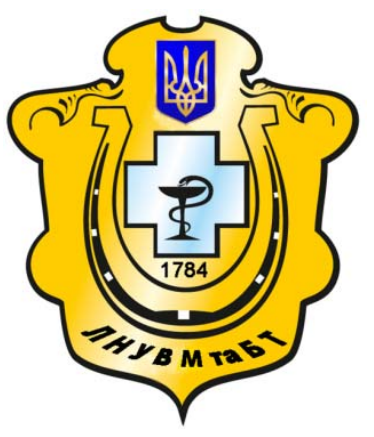

Науковий вісник Львівського національного університету ветеринарної медицини та біотехнологій імені С.3. Гжицького

Scientific Messenger of Lviv National University of Veterinary Medicine and Biotechnologies named after S.Z. Gzhytskyj

doi:10.15421/nvlvet7147

ISSN 2413-5550 print

ISSN 2518-1327 online

$\underline{\text { http://nvlvet.com.ua/ }}$

УДК 619:612.015: 636.2.

\title{
Активність амінотрансфераз у сироватці крові телят за дії піридоксину гідрохлориду
}

\author{
О.В. Яремко, Р.А. Пеленьо \\ olhaja@ukr.net
}

\begin{abstract}
Львівський наџіональний університет ветеринарної медицини та біотехнологій імені С.3. Гжицького, вул. Пекарська, 50, м. Львів, 79010, Украӥна
\end{abstract}

Вивчали вплив піридоксину гідрохлориду (вітаміну $B_{6}$ ) на активність амінотрансфераз у сироватиі крові телят молочного періоду вирощування (з 1 по 90 добу). Телята контрольної групи отримували основний раціон, а дослідним з першоі доби життя до основного рачіону додавали піридоксину гідрохлорид у дозах: I група - 1,0; II - 2,0; III - 3,0; IV - 4,0 та V група - 5,0 мг/кг маси тіла. Кров для дослідження брали перед ранковою годівлею на 1, 5, 21, 60 і 90 добу після народження. Дослідження активності амінотрансфераз визначали за вмістом у сироватиі крові аспартатамінотрансферази (АСТ), аланінамінотрансферази (АЛТ) та співвідномення між ними за допомогою коефіиієнту де Рітіса.

Встановлено, що додавання до молозива і молока піридоксину гідрохлориду веде до підвищення активності амінотрансфераз. Найнижча активність АСТ і АЛТ у сироватиі крові телят усіх груп була на першу добу життя. Дія піридоксину гідрохлориду на активність амінотрансфераз проявлялася впродовж дослідного періоду. Додавання до молозива вітаміну $B_{6}$ підвищує активність АCT на 10 і вище відсотків лище за доз 3,0, 4,0 і 5,0 мг/кг маси тіла. Вірогідно вищу активність ACT виявлено у тварин II, III, IV $i$ V груп на 21 та 60 добу. До 90 доби досліду активність АСT в сироватці крові телят дослідних груп стабілізувалася, що може свідчити про здатність вітаміну $B_{6}$ стимулювати ріст і розвиток мікрофлори рубия. Додавання до молозива і молока піридоксину гідрохлориду приводило до зростання в межах референтних значень активності АЛТ. Вірогідна різниця між активністю АЛТ контрольної і дослідних груп встановлена у телят III, IV $i$ V груп на 21, 60 і 90 добу досліду, та у телят II групи на 90 добу досліду. Стабілізаиія активності досліджуваного ферменту встановлена на 21 добу у телят IV групи, на 60 - III групи і на 90 добу у телят II групи. Відношення АCT до AЛT (коефіuієнт де Рітіса) не виходило за межі фізіологічної норми. Для корекиії вітамінного живлення телят 1-21 добового віку оптимальною дозою є щъоденна добавка до раціону телят 4 мг/кг маси тіла вітаміну $B_{6}$, для телят з 21-60 добового віку - 3 мг/кг маси тіла, а для телят 60-90 добового віку - 2 мг/кг маси тіла.

Ключові слова: фізіологія, телята, аланінамінотрансфераза, аспартатамінотрансфераза, коефіцієнт де Рітіса, сироватка крові, піридоксину гідрохлорид.

\section{Активность аминотрансфераз в сыворотке крови телят при действии пиридоксина гидрохлорида}

\author{
А.В. Яремко, Р.А. Пеленьо \\ olhaja@ukr.net
}

Львовский национальный университет ветеринарной медицины и биотехнологий имени С.3. Гжиџкого, ул. Пекарская, 50, г. Львов, 79010, Украина

Изучали влияние пиридоксина гидрохлорида (витамина $B_{6}$ ) на активность аминотрансфераз в сыворотке крови телят молочного периода выращивания (с 1 по 90 сутки). Телята контрольной группь получали основной рацион, а опытным $c$ первых суток жизни к основновному рачиону скармливали пиридоксина гидрохлорид в дозах: I группа - 1,0; II - 2,0; III - 3,0; IV - 4,0 и V группа - 5,0 мг / кг массы тела. Кровь для исследования отбирали перед утренним кормлением на 1, 5, 21, 60 u

\section{Citation:}

Yaremko, O.V., Pelenio, R.A. (2016). The activity of aminotransferases in the blood serum of calves on the effects of pyridoxine hydrochloride. Scientific Messenger LNUVMBT named after S.Z. Gzhytskyj, 18, 3(71), 209-213. 
90 сутки после рождения. Исследование активности аминотрансфераз определяли по содержанию в сыворотке крови аспартатаминотрансферазы (АСТ), аланинаминотрансферазы (АЛТ) и соотномения между ними с помощью коэффициента де Puтиса.

Установлено, что пиридоксин гидрохлорид ведет к повышению активности аминотрансфераз. Самая низкая активность АСТ и АЛТ в сыворотке крови телят всех групп была в первые сутки жизни. Действие пиридоксина гидрохлорида на

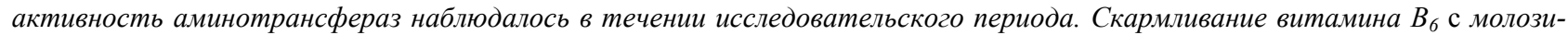
вом повышает активность АСТ на 10 и более процентов только за доз 3,0, 4,0 и 5,0 мг/кг массы тела. Вероятно высокую активность АCT обнаружено у животных II, III, IV и V групп на 21 и 60 сутки. До 90 суток опьта активность АСТ в сыворотке крови телят опытных групп стабилизировалась, что может свидетельствовать о способности витамина В 6 стимулировать рост и развитие микрофлоры рубца. Добавление пиридоксина гидрохлорида к молозиву и молоку привело к росту, в пределах физиологической нормы. активности АЛТ. Достоверная разница между активностью АЛТ контрольной и опытных групп установлена у телят III, IV и V групп на 21, 60 и 90 сутки опьта, и у телят II группь на 90 сутки опьтта. Стабилизация активности исследуемого фермента установлена на 21 сутки у телят IV группь, на 60 - III группь и на 90 сутки у телят II группь. Отночение АСТ к АЛТ (коэффициент де Ритиса) не выходило за предель физиологической нормы. Для коррекции витаминного питания телят 1-21 суточного возраста оптимальной дозой ежедневной добавки в рацион телят 4 мг/кг массы тела витамина $B_{6}$, для телят с 21-60 суточного возраста - 3 мг/кг массы тела, а для телят 60 90 суточного возраста - 2 мг/кг массы тела.

Ключевые слова: физиология, телята, АСТ, АЛТ, коэффициент де-Ритиса, сыворотка крови, пиридоксин гидрохлорид.

\title{
The activity of aminotransferases in the blood serum of calves on the effects of pyridoxine hydrochloride
}

\author{
O.V. Yaremko, R.A. Pelenio \\ olhaja@ukr.net \\ Lviv National University of Veterinary Medicine and Biotechnologies named after S.Z. Gzhytskyi, \\ Pekarska Str., 50, Lviv, 79010, Ukraine
}

The influence of pyridoxine hydrochloride (vitamin $B_{6}$ ) activity in serum aminotransferases in dairy calves growing period (1 to 90 days). Calves control group received basic diet, but research from the first days of life to the basic diet added pyridoxine hydrochloride doses: I group - 1.0; II - 2.0; III - 3.0; IV - $4.0 \mathrm{~V}$ and group - $5.0 \mathrm{mg} / \mathrm{kg}$ body weight. Blood for the study was before the morning feeding at 1, 5, 21, 60 and 90 days after birth. Research aminotransferase activity was determined by the content of serum aspartate aminotransferase (AST), alanine aminotransferase (ALT) and the ratio between them using factor where Ritisa.

It was established that the addition of colostrum to milk and pyridoxine hydrochloride leads to increased aminotransferase activity. The low activity of AST and ALT in blood serum of calves of all groups was on the first day of life. Effects of pyridoxine hydrochloride on aminotransferase activity was shown during the research period. Adding to the colostrum vitamin $B_{6}$ increases the activity of AST by 10 percent or more doses of only 3.0, 4.0 and $5.0 \mathrm{mg} / \mathrm{kg}$ body weight. Probably higher AST activity detected in animals II, III, IV and V groups at 21 and 60 days. On the 90th day of the experiment AST activity in serum of calves research groups stabilized, which may indicate the ability of vitamin $B_{6}$ stimulate the growth and development of microorganisms scar. Adding to the colostrum and milk pyridoxine hydrochloride led to growth within the physiological norm ALT activity. Significant difference between ALT control and experimental groups established in calves III, IV and V groups 21, 60 and 90 day experiment, calves and the second group on day 90 of the experiment. Stabilization of enzyme activity investigated is set to 21 days in calves group IV, 60 - the third group and 90 days in calves second group. The ratio of AST to ALT (coefficient de Ritis) do not go beyond the physiological norm. For correction of vitamin-supply calves 1-21 days old is the optimal dose of daily supplement intake of calves $4 \mathrm{mg} / \mathrm{kg}$ body weight of vitamin $B_{6}$ for calves with 21-60-day age - $3 \mathrm{mg} / \mathrm{kg}$ and 60 calves 90-day age - $2 \mathrm{mg} / \mathrm{kg}$ body weight.

Key words: physiology, calves, alanineaminotransferase, ashartateaminotransferase, ratio de Ritis, blood serum, pyridoxine hydrochloride.

\section{Вступ}

Серед ферментів, пов'язаних 3 обміном білка i амінокислот, важливе значення мають аспартатамінотрансфераза (АСТ) та аланінамінотрансфераза (АЛТ). Простетичною групою трансаміназ є піридоксальфосфат (ПАЛФ), який разом 3 піридоксином, пірідоксалем і піридоксаміном об'єднані під загальною назвою вітамін $\mathrm{B}_{6}$. Піридоксальфосфат регулює практично всі процеси білкового обміну - від всмоктування амінокислот в кишечнику та їх перетворень до синтезу нуклеїнових кислот і білків. Особливо важлива участь піридоксину в синтезі переносників заліза і гемоглобіну, скоротних білків міокарда, травних ферментів, у підтримці детоксикаційної і синтетичної функції печінки (Tymoshenko, 2003; Golovach and Zmija, 2010).
Беззаперечним є той факт, що у жуйних тварин забезпечення вітаміном $\mathrm{B}_{6}$, у значній мірі, задовольняється за рахунок його синтезу мікрофлорою рубця (Russel et al., 2005). Проте, науковцями школи С.В. Стояновського (Velichko, 1987; Kostjuk, 1988; Semanjuk, 1990; Jus'kyv, 1992; Stojanovs'kyj et al.,1993; Jaremko and Stojanovs'kyj, 1999) ще у 90-х роках доведено, що у телят молочного періоду вирощування рубець ще не функціонує і $є$ потреба у додатковому введенні піридоксину в раціон. Разом з цим, вибір дози і механізм дії піридоксину гідрохлориду на активність трансаміназ у телят молочного періоду вирощування так i залишається ще не достатньо вивченим, що має як теоретичний так і практичний інтерес. 


\section{Матеріал і методи досліджень}

Досліди проведено в агрофірмі «Медобори» Тернопільського району Тернопільської області на телятах 31 до 90 доби життя. За принципом аналогів було підібрано і сформовано шість груп (контрольна і п’ять дослідних) новонароджених телят, по 5 тварин в кожній. Всі піддослідні тварини були клінічно здоровими, їх годівля проводилась за збалансованими раціонами (Kalashnikov, 2003). Телята контрольної групи отримували основний раціон, а дослідним 3 першої доби життя до основного раціону додавали піридоксин гідрохлорид у різних дозах: I група - 1,0; II - 2,0; III 3,0; IV - 4,0 та V група - 5,0 мг/кг живої маси.

Відбір проб венозної крові для дослідження проводили перед ранковою годівлею на 1, 5, 21, 60 і 90 добу після народження. При проведенні досліджень у сироватці крові визначали активність аспартатамінотрансферази (КФ 2.6.1.1.) і аланінамінотрансферази (КФ 2.6.1.2.) за методикою S. Reitman, S. Frankel (1957) в модифікації К.Г. Капетанакі та співвідношення АСТ до АЛТ (коефіцієнт де Рітіса).

Усі експериментальні дослідження проведено відповідно до існуючих міжнародних вимог і норм гуманного ставлення до тварин (Страсбург, 1986 р., Закон України від 21.02.2006 р., № 3447-IV).
Статистичну обробку одержаних цифрових даних проводили за допомогою програми Statystika для Windows XP з використанням t-критерію Стьюдента. Визначали ступінь вірогідності різниці (р) між досліджуваними показниками тварин контрольної і дослідних груп на першому та другому етапі досліджень. Результати середніх значень вважали статистично вірогідними при $\mathrm{p}<0,05^{*} ; \mathrm{p}<0,01^{* * ;} \mathrm{p}<0,001 * * *$.

\section{Результати та їх обговорення}

Проведеними дослідженнями встановлено, що активність амінотрансфераз у сироватці крові телят досліджуваного періоду відрізнялася як у віковому аспекті, так і за дії різних доз піридоксину гідрохлориду (табл. 1). Так, у однодобових телят активність АСТ контрольної та дослідних груп тварин виявилася найнижчою i знаходилася в межах 1,26 1,36 мкмоль/л. Додавання телятам дослідних груп до молозива піридоксину протягом 5 діб привело до зростання активності досліджуваного ферменту у I групі на $10,3 \%$, II - 6,6\%, III - 10,6\%, IV - 14,8\% та у $\mathrm{V}$ групі $23,4 \%$, порівняно із першим днем життя тварин.

Активність аспартатамінотрансферази у сироватці крові телят молочного періоду вирощування, мкмоль/л (M $\pm \mathbf{m}, \mathbf{n}=\mathbf{5})$

\begin{tabular}{|c|c|c|c|c|c|}
\hline \multirow{2}{*}{ Групи тварин } & \multicolumn{5}{|c|}{ Мкмоль/л $(\mathbf{M} \mathbf{m} \mathbf{n}=\mathbf{5})$} \\
\cline { 2 - 6 } & 1 & 5 & 21 & 60 & 90 \\
\hline Контроль & $1,29 \pm 0,05$ & $1,36 \pm 0,03$ & $1,63 \pm 0,08$ & $1,74 \pm 0,06$ & $1,88 \pm 0,08$ \\
\hline I & $1,26 \pm 0,06$ & $1,39 \pm 0,05$ & $1,86 \pm 0,09$ & $1,94 \pm 0,08$ & $2,05 \pm 0,08$ \\
\hline II & $1,36 \pm 0,04$ & $1,45 \pm 0,05$ & $1,92 \pm 0,08^{*}$ & $2,04 \pm 0,09^{*}$ & $2,14 \pm 0,03^{* *}$ \\
\hline III & $1,32 \pm 0,04$ & $1,46 \pm 0,04$ & $1,99 \pm 0,05^{* *}$ & $2,12 \pm 0,08^{* *}$ & $2,15 \pm 0,04^{* *}$ \\
\hline IV & $1,35 \pm 0,05$ & $1,55 \pm 0,07$ & $2,13 \pm 0,06^{* * *}$ & $2,14 \pm 0,05^{* * *}$ & $2,15 \pm 0,04^{* *}$ \\
\hline V & $1,28 \pm 0,05$ & $1,58 \pm 0,09$ & $2,15 \pm 0,06^{* * *}$ & $2,16 \pm 0,05^{* * *}$ & $2,18 \pm 0,05^{* *}$ \\
\hline
\end{tabular}

Наведені у вище представленій таблиці дані свідчать, що протягом молозивного періоду у новонароджених телят досліджуваних груп відбувається наростання активності АСТ, а додавання до молозива піридоксину гідрохлориду, порівняно із контрольною групою, підвищує активність ферменту більше як на $10 \%$ лише за доз 3,0, 4,0 і 5,0 мг/кг маси тіла.

У молочний період на 21 добу досліду, порівняно iз 1 добою, нами відмічено зростання активності АСТ у телят контрольної і дослідних груп. Згодовування телятам піридоксину гідрохлориду привело до зростання активності досліджуваного ферменту, порівняно із контрольною групою телят, у I групі на 14,1\%, II - на $17,8 \%$, III - на 22,1, IV - на 30,7\% і у V групі - на 31,9\%. Вірогідно вищу активність АСТ виявлено у тварин II групи (p < 0,05), яким до молока додавали піридоксину гідрохлорид у дозі 2 мг/кг маси тіла, III групи (р < 0,01), які одержували 3 мг/кг маси тіла вітаміну та IV i V груп (р < 0,001), які одержували разом з молоком піридоксину гідрохлорид у дозі 4 i 5 мг/кг маси тіла.

Згодовування піридоксину гідрохлориду телятам протягом 60 діб привело до подальшого наростання активності АCТ, відносно контрольної групи, у I групі на $11,5 \%$, II - на $17,2 \%$, III - на 21,8, IV - на $23,0 \%$ та у V групі - на 24,1\%. Вірогідно вищою виявилася різниця у телят II групи ( $<<0,05)$, III групи $(\mathrm{p}<0,01)$, IV i V груп $(\mathrm{p}<0,001)$.

На 90 добу досліду нами не відмічено суттєвої різниці в активності АСТ в крові телят дослідних груп порівняно з 60 добовими тваринами.

Результати вивчення активності АЛТ в крові телят молочного періоду за дії піридоксину гідрохлориду представлені в таблиці 2.

3 аналізу результатів наведених у таблиці 2 видно, що активність АЛТ на першу добу життя телят досліджуваних груп становила від 0,99 до 1,04 мкмоль/л, що не виходить за межі референтних значень. Додавання до молозива піридоксину гідрохлориду приводило до зростання активності АЛТ на 5 добу порівняно 3 першою добою життя тварин. Вірогідна різниця між активністю АЛТ контрольної і дослідних груп нами встановлена у телят III, IV i V груп на 21, 60 i 90 добу досліду, а також у телят II групи на 90 добу досліду. Необхідно відмітити, що активність досліджуваного ферменту стабілізувалася на 21 добу у телят IV групи, на 60 - III групи і на 90 добу у телят II групи. 
Табличя 2

Активність аланінамінотрансферази у сироватці крові телят молочного періоду вирощування, мкмоль/л $(\mathbf{M} \pm \mathbf{m}, \mathbf{n}=\mathbf{5})$

\begin{tabular}{|c|l|l|l|l|l|}
\hline Групи тварин & \multicolumn{3}{|c|}{ Доба } & \multicolumn{1}{|c|}{21} & 60 \\
\cline { 2 - 5 } & \multicolumn{1}{|c|}{1} & \multicolumn{1}{|c|}{5} & \multicolumn{1}{|c|}{90} & $1,11 \pm 0,06$ \\
\hline Контроль & $1,01 \pm 0,04$ & $1,01 \pm 0,05$ & $1,07 \pm 0,03$ & $1,19 \pm 0,08$ \\
\hline I & $1,03 \pm 0,06$ & $1,10 \pm 0,06$ & $1,17 \pm 0,05$ & $1,24 \pm 0,07$ \\
\hline II & $1,04 \pm 0,04$ & $1,09 \pm 0,06$ & $1,21 \pm 0,06$ & $1,23 \pm 0,08$ \\
\hline III & $0,99 \pm 0,04$ & $1,12 \pm 0,07$ & $1,25 \pm 0,07^{*}$ & $1,31 \pm 0,04^{*}$ \\
\hline IV & $1,04 \pm 0,06$ & $1,15 \pm 0,08$ & $1,33 \pm 0,04^{* *}$ & $1,33 \pm 0,04^{* *}$ & $1,30 \pm 0,04^{*}$ \\
\hline V & $1,02 \pm 0,05$ & $1,14 \pm 0,06$ & $1,33 \pm 0,04^{* *}$ & $1,32 \pm 0,04^{*}$ & $1,32 \pm 0,04^{*}$ \\
\hline
\end{tabular}

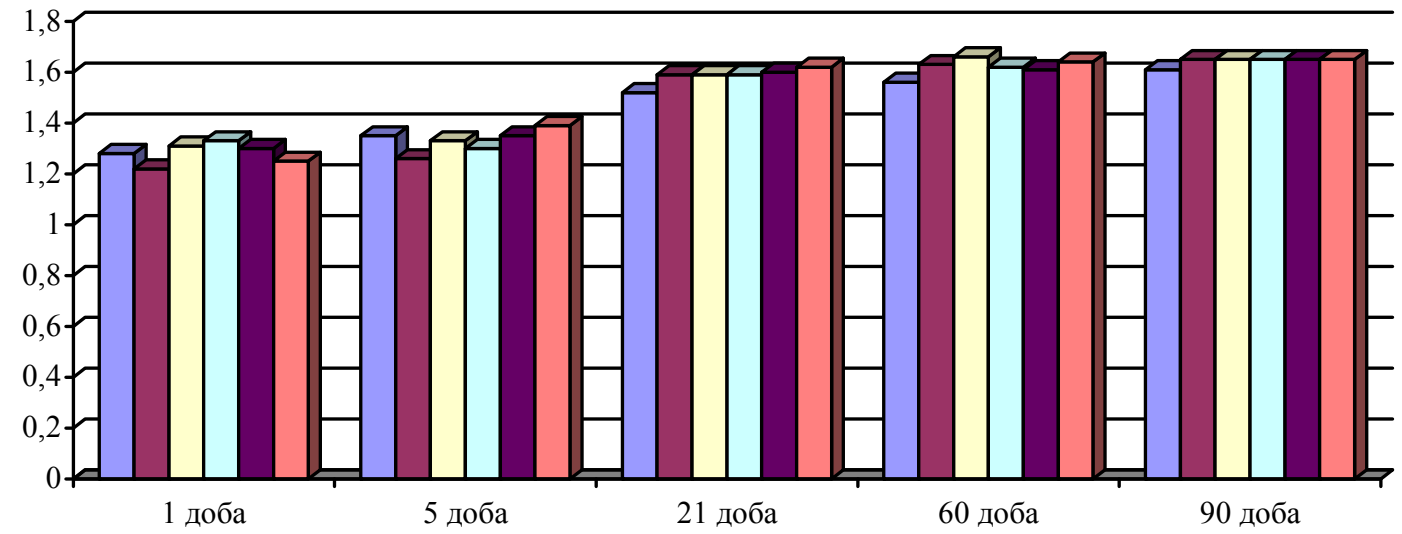

\begin{tabular}{|c|c|c|c|c|c|}
\hline 口Контроль & 口 I група & 口 II група & 口 III група & 口IV група & $\square$ V група \\
\hline
\end{tabular}

Рис. 1. Коефіціснт де Рітіса. $(\mathrm{n}=5)$

Це вказує, що оптимальною дозою піридоксину гідрохлориду з 1 доби життя є 5 мг/кг маси тіла, з 21 4 мг/кг маси тіла, з $60-3$ мг/кг маси тіла і з 90 добового віку -2 мг/кг маси тіла.

В клінічній практиці важливе значення має не тільки визначення активності трансаміназ (АСТ, АЛТ) в крові, але і їх співвідношення, яке вираховується за допомогою коефіцієнту де Рітіса.

Із результатів наведених на рис.1 видно, що коефіцієнт де Рітіса не виходить за межі референтних значень для тварин $(0,91-1,75)$. Проте, звертає на себе увагу зростання коефіцієнта на 21 добу життя, порівняно із молозивним періодом, а також після 21 доби за додаткового згодовування телятам піридоксину гідрохлориду.

\section{Висновки}

Протягом молозивного періоду у новонароджених телят відбувається наростання активності АСТ і АЛТ, а додавання до молозива піридоксину гідрохлориду підвищує, порівняно із контрольною групою тварин, активність ферментів більше як на 10 і вище відсотків лише за доз 3,0, 4,0 і 5,0 мг вітаміну на 1 кг живої маси.

2. Згодовування телятам протягом 90 днів піридоксину гідрохлориду приводить до поступового наростання у крові активності АСТ та АЛТ і швидшого становлення рубцевого травлення, порівняно із телятами контрольної групи.
3. На 21 добу життя, порівняно із молозивним періодом, а також після 21 доби за додаткового згодовування телятам піридоксину гідрохлориду відмічено зростання коефіцієнта де Рітіса.

\section{Бібліографічні посилання}

Tymoshenko, O.P. (2003). Klinichna biohimija: navch. posibn. H. (in Ukrainian).

Golovach, P.I., Zmija, M.M. (2010). Obmin bilkiv u bugajciv na vidgodivli za vplyvu vitaminiv grupy $\mathrm{V}$ (V1, V2, V5, V6, V10, V12). Naukovyj visnyk L'vivs'kogo nacional'nogo universytetu veterynarnoi' medycyny i biotehnologij im. S.Z. Gzhyc'kogo. L'viv. 12(3), 28-30 (in Ukrainian).

Russel, L.E. Faster, R.A., Bechtel, P.J. (2005). Evaluation of the erythrocycle aspartate aminotransferase activity coefficient as an indicator of port pubertal gilts. J. Nutrit. 115(5), 1117-1123.

Velichko, V.A. (1987). Osobennosti obmena veshhestv u bychkov $\mathrm{V}$ uslovijah promyshlennoj tehnologii proizvodstva govjadiny: avtoref. dis. na soiskanie uchenoj stepeni kand. biol. nauk: spec. 03.00.13 «Fiziologija cheloveka i zhivotnyh». L'vov (in Russian).

Kostjuk, S.S. (1988). Vlijanie piridoksina na pokazateli belkovogo i gazo-jenergeticheskogo obmena $u$ krupnogo rogatogo skota $\mathrm{v}$ ontogeneze: avtoref. dis. na soiskanie uchenoj stepeni kand.biol.nauk : spec. 
03.00.13 «Fiziologija cheloveka i zhivotnyh». L'vov (in Russian).

Semanjuk, V.I. (1990). Vlijanie piridoksina na pokazateli jenergeticheskogo i lipidnogo obmena u krupnogo rogatogo skota $\mathrm{v}$ ontogeneze : avtoref. dis. na soiskanie uchenoj stepeni kand. biol. nauk : spec. 03.00.13 «Fiziologija cheloveka i zhivotnyh». L'vov (in Russian).

Stojanovs'kyj, S.V., Stupnyc'kyj, R.M., Cymbala, V.I. (1993). Zastosuvannja pirydoksynu dlja korekcii' obminnyh procesiv i pidvyshhennja produktyvnosti hudoby. Naukovo-metodychni aspekty fiziologii': L'viv. 2(2), 152-153 (in Ukrainian).
Jus'kyv, Y.D. (1992). Pokazately yonnogo sostava sыvorotky krovy suhostojnыh korov y rodyvshyhsja ot nyh teljat pod vlyjanyem vytamyna V6 y magnyja : avtoref. dys. na soyskanye uchenoj stepeny kand. byol. nauk : spec. 03.00.13 «Fyzyologyja cheloveka y zhyvotnыh». L'vov (in Ukrainian).

Jaremko, O.V., Stojanovs'kyj, S.V. (1999). Vplyv pirydoksynu na obmin vuglevodiv u teljat. Naukovotehnichnyj bjuleten' instytutu zemlerobstva i biologii' tvaryn UAAN. L'viv. 1(3), 91-93 (in Ukrainian).

Kalashnikov, A.P. (2003). Normy i raciony kormlenija sel'skohozjajstvennyh zhivotnyh: spravochnoe posobie. 3-e izd., pererab. i dop. (in Russian).

Стаття надійшла до редакиії 5.09.2016 